\title{
Genome Size, Ploidy, and Base Composition of Wild and Cultivated Acer
}

\author{
Ryan N. Contreras ${ }^{1,3}$ and Kimberly Shearer ${ }^{2}$ \\ Department of Horticulture, Oregon State University, 4017 Agricultural and Life Sciences Building, \\ Corvallis, OR 97331
}

\begin{abstract}
AdDitional InDEX wORDs. Sapindaceae, chromosome number, flow cytometry, cytology
Abstract. Acer is a large and important genus of woody plants most commonly encountered as small to large trees in urban landscapes. Considerable investigation has been devoted to addressing the taxonomy of maples, but little is known about genome sizes across the genus. Relatively more work has been conducted to determine chromosome numbers and ploidy of more species, but much could be gained by expanding knowledge of genome sizes in combination with traditional cytology. Furthermore, base pair (bp) composition may have implications for a species' adaptability and also impacts nucleic acid stability at high temperatures. Our objectives were to determine the genome size of 195 accessions of maples, assign ploidy to each using inference as well as cytology, and determine base composition of a subset of 48 accessions. Most species had small genome sizes (1.4-3.5 pg) with the exception of section Rubra, which contains many polyploids. Holoploid genome sizes ranged from 1.39 to $6.10 \mathrm{pg}$, with the latter being interpreted as $9 x$. The mean monoploid genome sizes (1Cx) ranged from $0.43 \mathrm{pg}$ in $A$. carpinifolium (section Indivisa) to $1.66 \mathrm{pg}$ in A. caudatifolium (section Macrantha); mean monoploid genome sizes were significantly different among sections. Forty-four of the 48 accessions measured using both fluorochromes had greater estimates with $4^{\prime}$, 6diamidino-2-phenylindole (DAPI) than propidium iodide (PI). The proportion of the genome composed of guanosine and cytosine (GC\%) among the taxa evaluated in this study ranged from just $38.61 \%$ to $43.96 \%$ and did not appear to be related to ecological adaptability or urban tolerance among these taxa.
\end{abstract}

Acer is a diverse genus including shrubs, medium-size trees, and large shade trees, with species creating a continuum of these forms. Maples are highly diverse in habitat, habit, bark, leaf shape and size, vegetative buds, and inflorescence structure. Opposite leaves and characteristic schizocarps of joined samaras are the two unifying morphological characters. Maples are grown primarily for fall color, bark, and form. The importance of maples produced in cultivation as street trees, specimen trees, or shade trees is reflected in the 2014 U.S. Department of Agriculture Census of Horticultural Specialties (U.S. Department of Agriculture, 2016), which reported the overall sales of maples as $\$ 173.4$ million nationwide. Oregon reported sales of maple in 2014 were more than $\$ 63$ million, which accounted for greater than half the value of deciduous shade trees statewide.

There has been considerable taxonomic research in attempting to determine the classification of species within the genus and how these species relate to one another on the evolutionary timescale (Ackerly and Donoghue, 1998; Grimm et al., 2006; Li, 2011; Li et al., 2006; Pfosser et al., 2002; Renner et al., 2008; Suh et al., 2000; Tian et al., 2002; Zhang et al., 2010). There has also been much debate relative to these taxonomic

Received for publication 4 Sept. 2018. Accepted for publication 1 Oct. 2018. Research funded in part by the J. Frank Schmidt Family Charitable Foundation and by HATCH funds.

We thank Mara Friddle for her technical support. We also thank the gardens, arboreta, and nurseries that generously provided plant material, including Arnold Arboretum (Boston, MA), Cornell Plantations (Ithaca, NY), Hoyt Arboretum (Portland, OR), J. Frank Schmidt Arboretum (Boring, OR), Morris Arboretum (Philadelphia, PA), Morton Arboretum (Lisle, IL), Quarry Hill Botanical Garden (Glen Ellen, CA), U.S. National Arboretum (Washington, DC), and Whitman Farms (Salem, OR).

${ }^{1}$ Associate Professor

${ }^{2}$ Tree and Shrub Breeder

${ }^{3}$ Corresponding author. E-mail: ryan.contreras@oregonstate.edu. relationships and phylogenetic order of the genus. This difference of opinion among taxonomists is illustrated by the disparity of species number, which varies from 129 to 200 , depending on taxonomic treatment ( $\mathrm{Li}, 2011$; Suh et al., 2000; Zhang et al., 2010). Although many teams are working on clarifying taxonomy, relatively little has been reported on genome size and ploidy level within the genus. Three original papers (Loureiro et al., 2007; Olszewska and Osiecka, 1984; Siljak-Yakovlev et al., 2010) reported genome sizes of 11 species of maples as part of larger studies. Depending on taxonomic treatment in these reports, between $6 \%$ and $9 \%$ of species have been reported. Clearly, for such an ecologically and economically important species, this is a significant gap in our scientific knowledge.

Genome size data have been shown to reflect taxonomic relationships in Cornaceae (Shearer and Ranney, 2013) while also being reflective of genome evolution (Johnston et al., 2005; Yotoko et al., 2011). Genome size data can be used to determine ploidy in a genus when calibrated properly using chromosome counts, as demonstrated for the Ericaceae, Cornaceae, Magnoliaceae, Berberidaceae, and Lamiaceae (Contreras and Ruter, 2011; Jones et al., 2007; Parris et al., 2010; Rounsaville and Ranney, 2010; Shearer and Ranney, 2013). Genome size and ploidy data are useful tools in a breeding program because they can provide greater insight into a genus and thus aid in developing breeding strategies.

The base chromosome number of Acer is $x=13$. Cytological reports for maples include a range of ploidy levels (Darlington and Wylie, 1956). The greatest occurrence of natural polyploidy has been reported in section Rubra including hexaploid $(2 n=6 x=78)$ A. pycnanthum, hexaploid and octoploid $(2 n=$ $8 x=104)$ A. rubrum, and tetraploid $(2 n=4 x=52)$, hexaploid, and aneuploid $(2 n=4 x+1=53)$ A. saccharinum (Duffield, 1943; Foster, 1933; Santamour, 1965, 1971). Tetraploids have 
also been reported in section Acer (A. heldreichii, A. pseudoplatanus, $A$. saccharum, and $A$. velutinum), section Indivisa ( $A$. carpinifolium), and section Platanoidea (A. campestre) (Foster, 1933; Santamour, 1965, 1971, 1988; Taylor, 1920). Most other maples investigated have been reported as diploid $(2 n=2 x=$ 26) (Table 1).

Polyploidy, or whole-genome duplication, can be used to facilitate wide hybrid crosses (Sanford, 1983) or to develop sterile ornamental cultivars with odd-ploidy levels such as triploids (Olsen et al., 2006; Trueblood et al., 2010). Variation in ploidy can also provide a barrier to successful hybridization in some cases (Sanford, 1983), and thus knowledge of ploidy in a group of taxa can be greatly beneficial in a developing breeding program.

Measuring genome size in plants can be accomplished quickly and effectively using flow cytometry, as demonstrated

Table 1. Previously reported chromosome numbers and holoploid (2C) genome sizes (measured in picograms) for Acer species evaluated in this study.

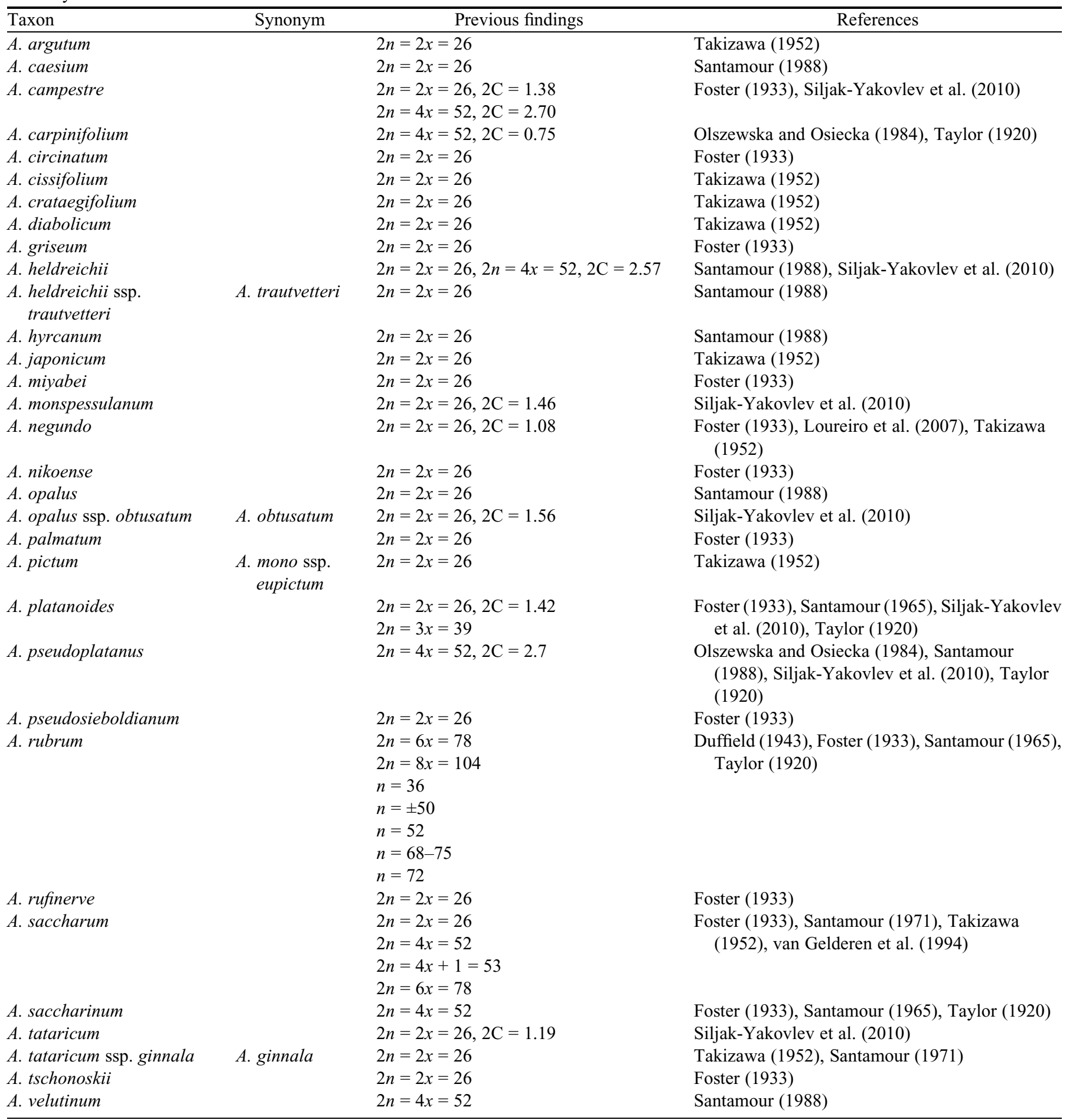


by a number of genome size surveys of angiosperms (Jones et al., 2007; Lattier et al., 2014; Parris et al., 2010; Rounsaville and Ranney, 2010; Shearer and Ranney, 2013). Although these genome size and ploidy surveys are useful to ornamental plant breeders, they also answer the call put forth by Galbraith et al. (2011), who proposed a coordinated global census of genome size of angiosperms. According to them, genome size and ploidy data can aid in developing priorities for whole-genome sequencing. The Plant DNA C-values Database, an online repository for genome size data, has become an invaluable tool for accessing these data to allow breeders and other researchers easy access (Bennett and Leitch, 2012).

There are a number of fluorochromes, or stains, that can be used for flow cytometry. For genome sizing, the most commonly used stains are DAPI and PI. These two fluorochromes have contrasting binding characters. DAPI binds to A-T-rich regions of the nuclear genome whereas PI is an intercalating agent that binds indiscriminately to all nucleic acids, including RNA. These contrasting binding characters can be used to infer the base composition of a genome (Meister and Barow, 2007; Parris et al., 2010; Rothleutner et al., 2016). Base composition can be expressed as either $\mathrm{GC} \%$, for proportion of genome composed of guanine and cytosine, or as $\mathrm{AT} \%$, for proportion of genome composed of adenine and thymine. Although our work regarding genome size and ploidy is applied in nature and geared to support our breeding program, there are various hypotheses regarding the impact of varying $\mathrm{GC} \%$ in plant genomes. Šmarda et al. (2014) reported genome sizes of 239 species of monocots and found that increased GC content was associated with species adapted to cold and/or dry environments. A major component of many woody plant breeding programs today is the development of plants that can tolerate such harsh conditions in our changing climate, including extreme cold, heat, and drought. Knowledge of base composition in woody plants may provide additional insight into the relationship between $\mathrm{GC} \%$ and climatic adaptability. However, caution should be used to draw correlations between observations in monocots to trees such as maples. Furthermore, it should be noted that there are inherent differences between monocots and dicots beyond obvious morphological differences. Although their study was limited in scope, $\mathrm{Li}$ and $\mathrm{Du}$ (2014) reported that dicots (34\%) have a lower GC\% compared with monocots $(46 \%)$.

The objectives of the current study were to determine relative genome sizes and ploidy levels of a diverse and wide-ranging selection of taxa within Acer, providing a foundation to facilitate future breeding efforts; to determine the base composition of a subset of maples in this study; and to contribute to the growing body of knowledge of genome size in angiosperms.

\section{Materials and Methods}

Plant material. Relative genome size was determined for 195 accessions representing 88 species and 18 taxonomic sections (Table 2). Plant material from Heritage Seedlings (Salem, OR), Hoyt Arboretum (Portland, OR), J. Frank Schmidt (Boring, OR), and Whitman Farms (Salem, OR) was collected onsite. Other plant material was collected and shipped to Oregon State University (OSU) by staff at the following institutions: Arnold Arboretum (Harvard University, Boston, MA), Cornell Plantations (Cornell University, Ithaca, NY), Morris Arboretum (University of Pennsylvania, Philadelphia,
PA), The Morton Arboretum (Lisle, IL), Quarry Hill Botanical Garden (Glen Ellen, CA), and the U.S National Arboretum (Washington, DC). Terminal stem cuttings from each accession were collected and placed in plastic bags. Cuttings sent from other institutions were shipped overnight with ice packs. All material was kept refrigerated at $4{ }^{\circ} \mathrm{C}$.

Collection information associated with material was provided by institutions directly or through public databases; in some cases, collection information such as Chinese province information was inferred through publicly available literature reporting and summarizing plant collection expeditions (Aiello and Dosmann, 2010; The Arnold Arboretum of Harvard University, 2016). Taxonomic relationships were adapted from van Gelderen et al. (1994), eFlora (2016), and Li (2016). Documentation of analyzed material includes deposition of herbarium vouchers at the OSU Herbarium (Corvallis, OR) or field planting of live plants at our research farm (Corvallis, OR) (Table 2). We used identification provided by the source. To our knowledge, the only area of confusion was related to red maple (A. rubrum) and freeman maple (A. xfreemanii), which often are used interchangeably depending on the nursery.

Flow CYTOMetry. The relative 2C genome sizes were determined using flow cytometry. Pisum sativum 'Ctirad' $(2 \mathrm{C}=8.76 \mathrm{pg})$ was used as an internal standard based on its common use as a reference standard (Bai et al., 2012; Greilhuber et al., 2007). Three samples were analyzed for each accession. For each sample, 1 to $2 \mathrm{~cm}^{2}$ or $20 \mathrm{mg}$ fresh expanding leaf and vegetative bud tissue were finely cochopped with $P$. sativum 'Ctirad' in a polystyrene petri dish with $400 \mu \mathrm{L}$ nuclei extraction buffer (Cystain ${ }^{\circledR}$ Ultraviolet Precise P Nuclei Extraction Buffer; Partec, Görlitz, Germany) using a sharp double-sided razor blade. The nuclei suspension was then filtered into sample tubes through $30-\mu \mathrm{m}$ gauze filters (Celltrics ${ }^{\circledR}$, Partec) and stained with $1.6 \mathrm{~mL}$ DAPI staining buffer (Cystain Ultraviolet Precise P Staining Buffer, Partec). For base composition analysis, a subset of samples was measured following the same methods for chopping and filtering using $500 \mu \mathrm{L}$ nuclei extraction buffer and $1.5 \mathrm{~mL}$ PI solution. PI solution contained PI, RNase, and staining buffer; and was prepared according to manufacturer instructions (Cystain ${ }^{\circledR}$ PI Absolute P, Partec). After staining, samples were incubated on ice in the dark for at least 20 min to allow RNase digestion of RNA. Relative genome size was determined using a flow cytometer (Cyflow ${ }^{\circledR}$ Ploidy Analyser, Partec), with excitation appropriate for each fluorochrome- 488 $\mathrm{nm}$ for DAPI and $532 \mathrm{~nm}$ for PI. Relative genome size (2C) DNA contents was calculated as

$$
\begin{aligned}
2 \mathrm{C}= & \text { DNA content of standard } \\
& \times \frac{\text { Mean fluorescence value of sample }}{\text { Mean fluorescence value of the standard }} .
\end{aligned}
$$

The relationship between ploidy level and genome size was determined initially using cytogenetically documented data (Table 1). Mean 1Cx genome size was calculated as (Mean $2 \mathrm{C}$ genome size/Inferred ploidy level) for each accession. For taxa with biological replicates, the mean $1 \mathrm{Cx}$ genome size reported in Table 3 reflects the monoploid genome size across all accessions of that taxa that were measured; whereas, in cases when biological replicates were not available, mean $1 \mathrm{C} x$ genome size was calculated using three samples measured from a single accession. 


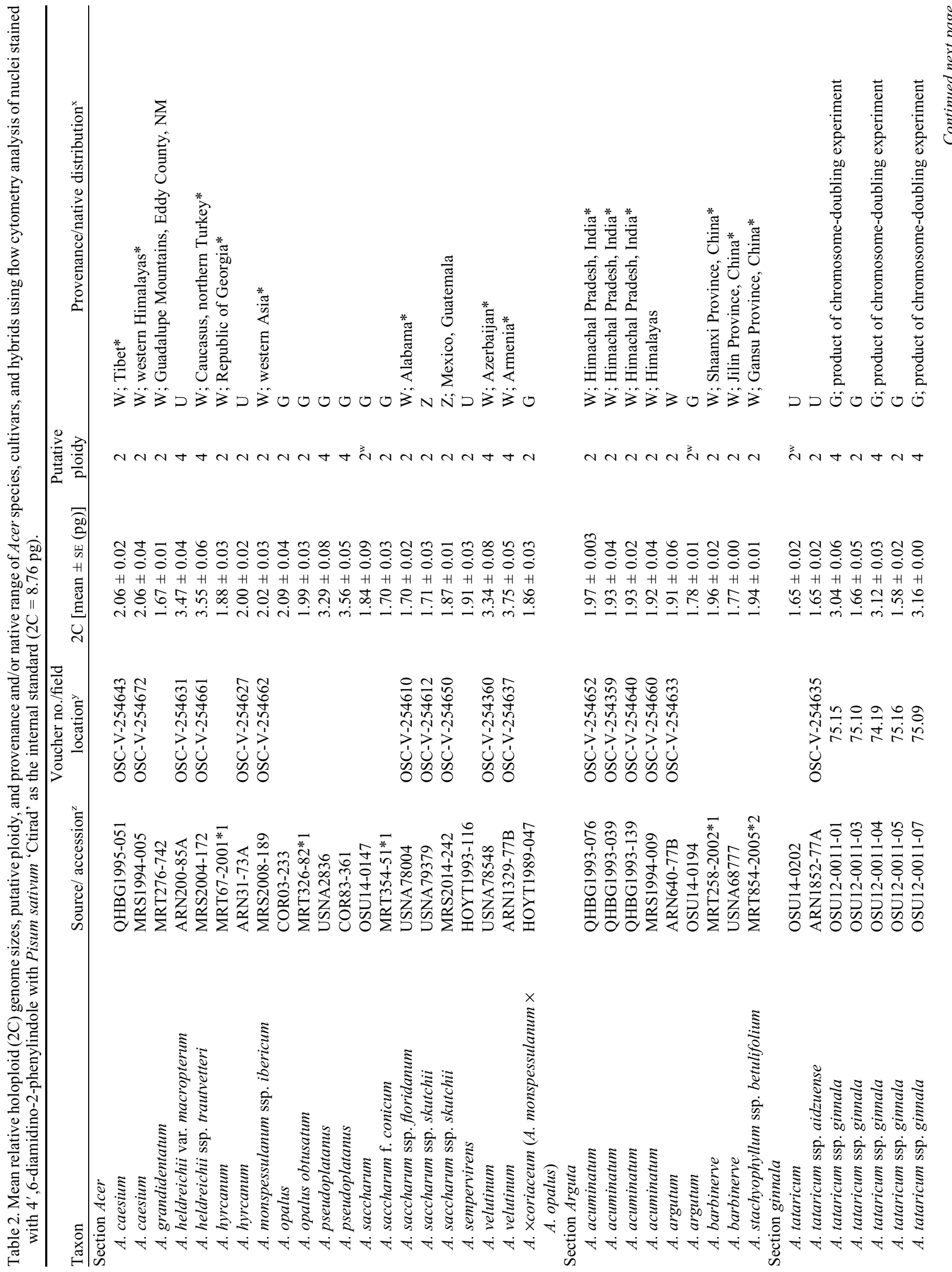




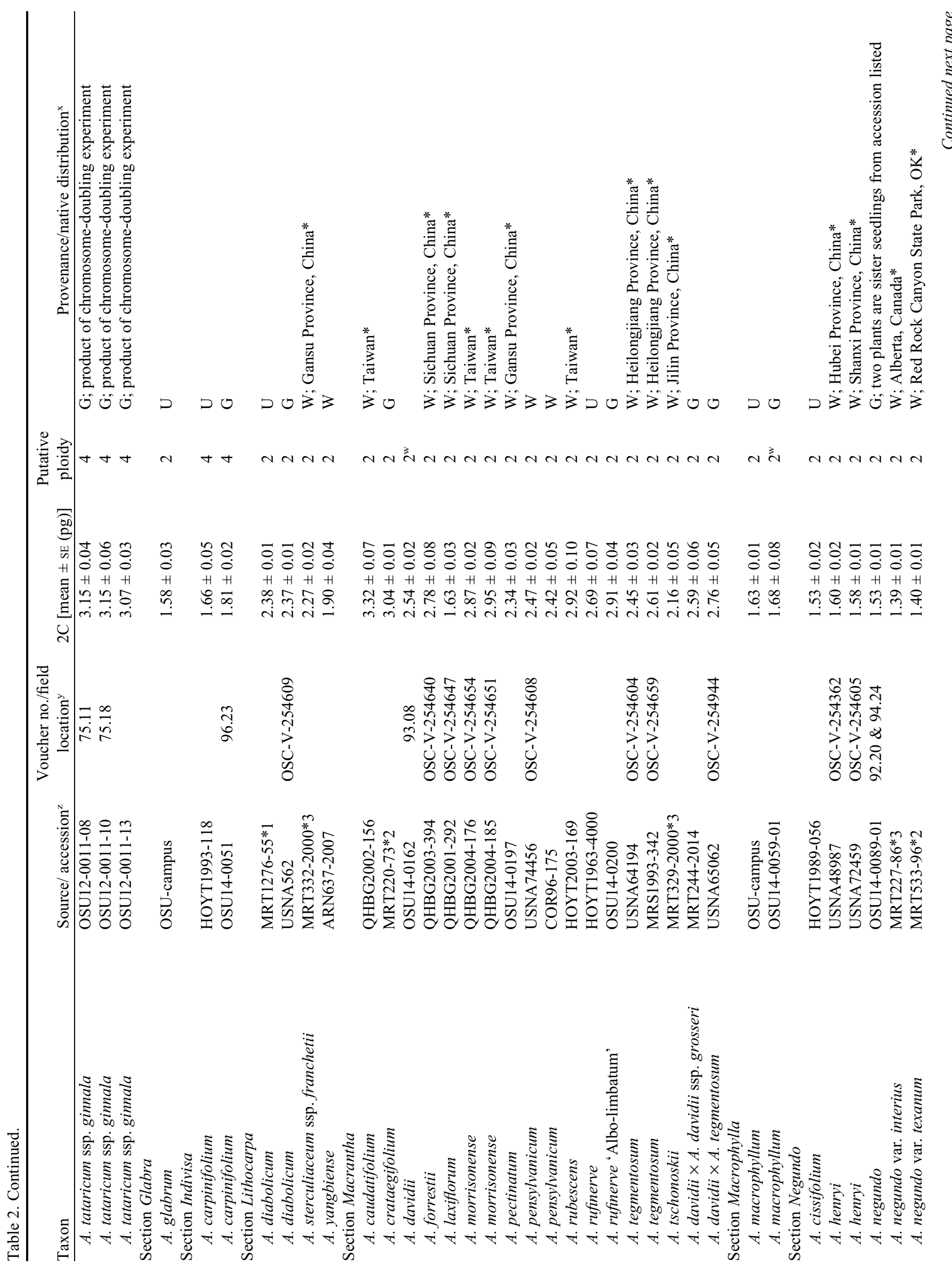




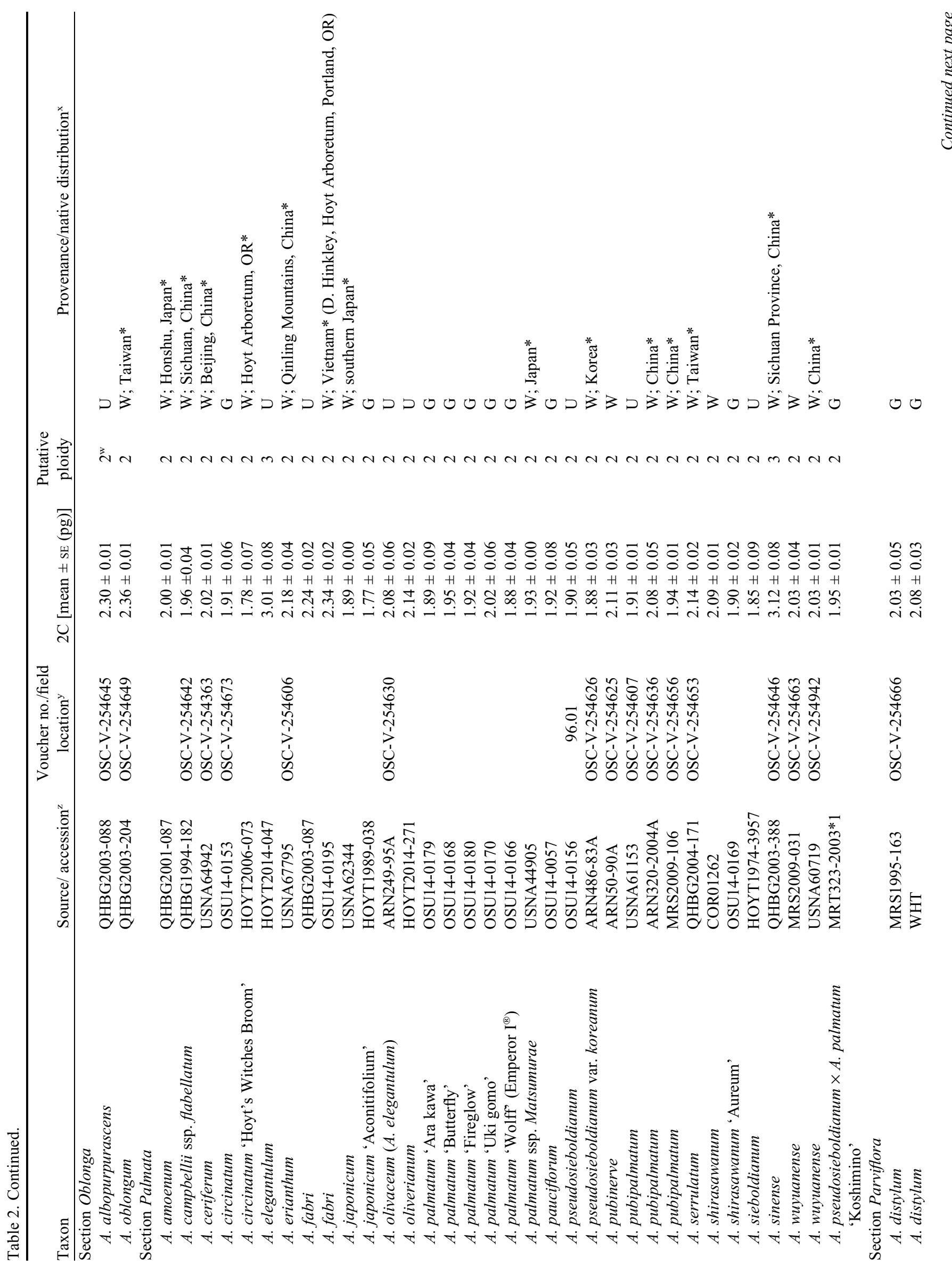




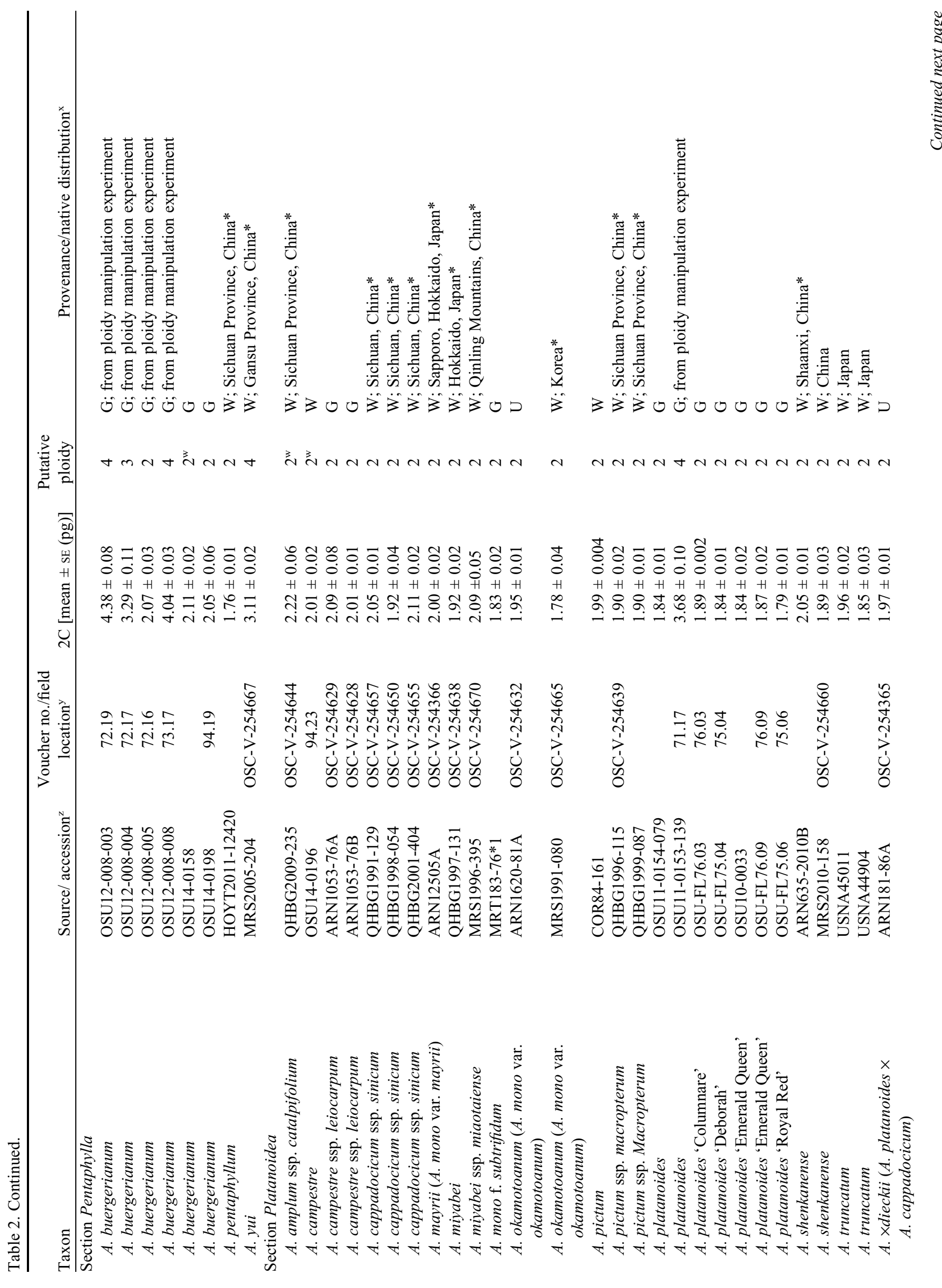




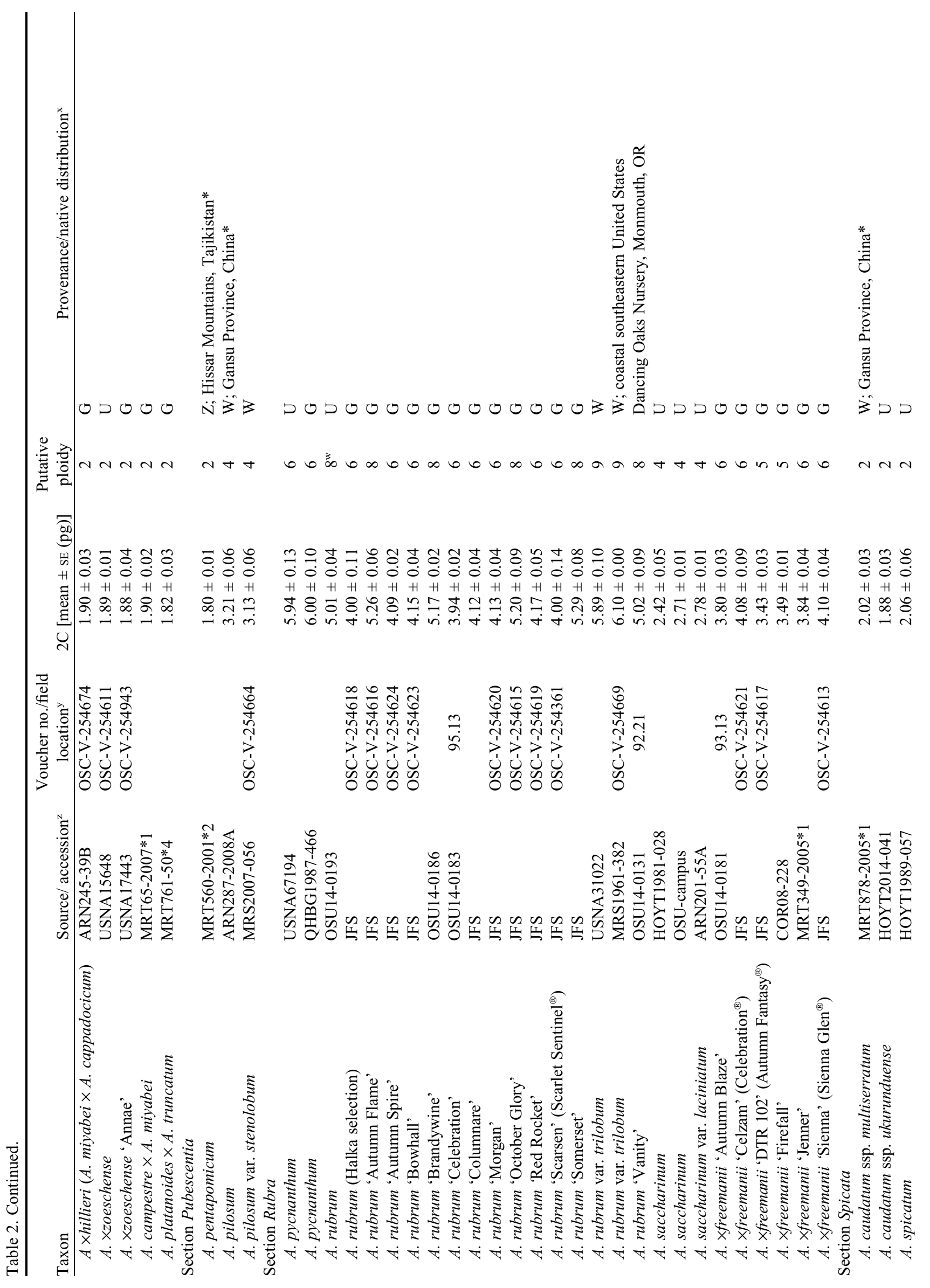




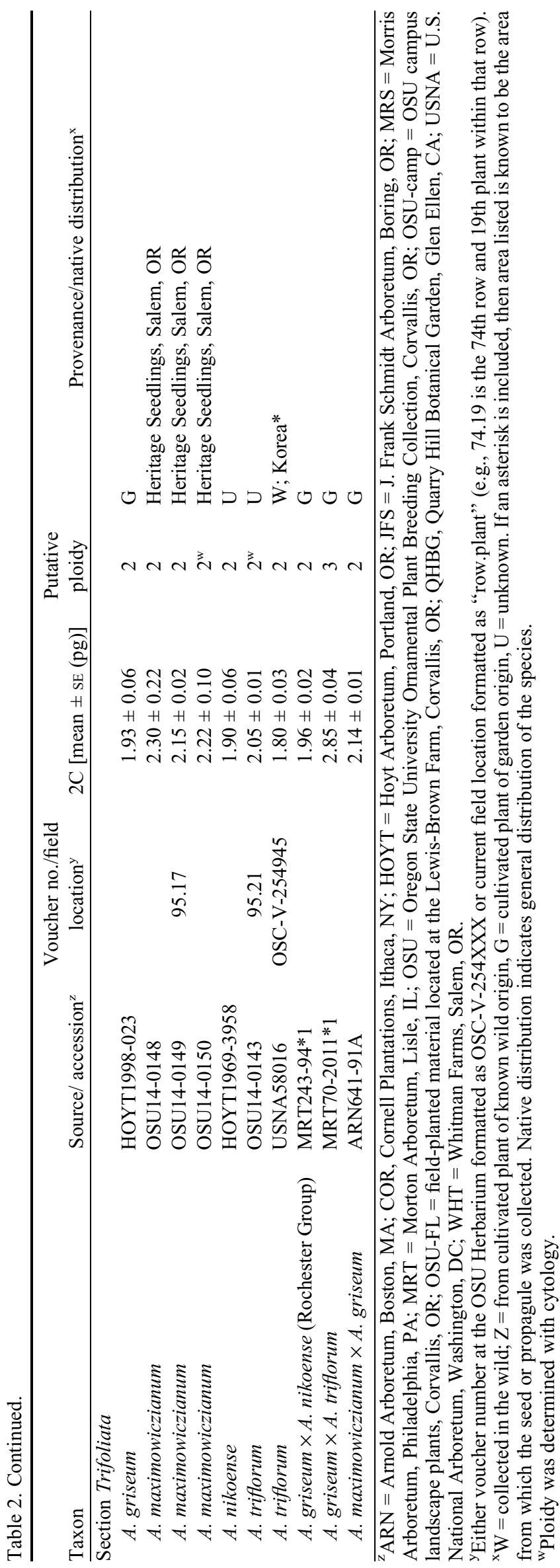

The bp composition of 48 accessions representing 17 taxonomic sections was evaluated. Base pair composition was estimated according to the equation: $\mathrm{AT} \%=\mathrm{AT} \%$ for internal standard $\times[$ (mean fluorescence standard DAPI / mean fluorescence sample DAPI) / (mean fluorescence standard PI / mean fluorescence sample PI) $]^{\text {(1/binding length) }}$ (Godelle et al., 1993), where $\mathrm{AT} \%$ of internal standard is 61.5 and the binding length of DAPI is $3.5 \mathrm{bp}$ (Meister and Barow, 2007) (Table 4). Values reported in Table 4 were calculated as $\mathrm{GC} \%=100-\mathrm{AT} \%$.

Cytology. Cytology was completed on 12 species representing nine taxonomic sections (Fig. 1), including diploids and one octoploid. For cytological analysis, cuttings were rooted or plants were grown from seed. Actively growing root tips were collected before 1100 HR on mornings following two sunny days. Roots tips were suspended in a prefixative solution of $2 \mathrm{~mm}$ 8-hydroxyquinoline $+0.24 \mathrm{~mm}$ cycloheximide in glass vials and incubated in the dark on ice for $3 \mathrm{~h}$. After the prefixative treatment, root tips were rinsed three to four times in distilled water and placed in Carnoy's solution (1 glacial acetic acid : 3 chloroform : 6 100\% ethanol) and incubated in the dark at room temperature overnight. The following morning, root tips were rinsed four times using $70 \%$ aqueous ethanol and then stored at $4{ }^{\circ} \mathrm{C}$ in vials of $70 \%$ ethanol until observation.

In preparation for enzyme digestion, tissue was excised from root apical meristems using a scalpel. A $0.5 \%$ enzyme solution including cellulase, pectolyase, and cytohelicase dissolved in $50 \mathrm{~mm}$ citrate buffer was used to break down cell walls. Root tips were placed in an Eppendorf tube containing enzyme solution, the tube was floated in a water-filled beaker, and was incubated for $\approx 3 \mathrm{~h}$ at $\approx 32{ }^{\circ} \mathrm{C}$. After incubation, excised tissue was removed from the tube using a glass pipette and was placed on a microscope slide. Excess liquid was wicked away using single-ply low-lint tissue. A drop of modified carbol fuchsin (Kao, 1975) was placed on the excised tissue, then a coverslip was placed on top. After $3 \mathrm{~min}$, the material was gently squashed. Slides were scanned and micrographs were captured using a light microscope at $630 \times$ and $1000 \times$ [Axio imager.A1 (Zeiss, Thornwood, NY), AxioCam MRm (Zeiss)]. A minimum of three to five cells were counted for each accession.

Statistical analyses. Analysis of variance was performed on monoploid genome sizes using PROC GLM (SAS version 9.4; SAS Institute, Cary, NC), and Tukey's honestly significant difference test at $\alpha=0.05$ was used to separate means of each section. A paired $t$ test was used to compare holoploid genome sizes for 48 taxa calculated using both DAPI and PI to determine whether differences were significant using these two fluorochromes.

\section{Results and Discussion}

With few exceptions, Acer had genome sizes in the range considered "small" (1.4-3.5 pg) using the definition used by Soltis et al. (2003). The $2 \mathrm{C}$ relative genome size ranged from $1.39 \mathrm{pg}$ in A. negundo var. interius to $6.10 \mathrm{pg}$ in A. rubrum var. trilobum (Table 2). The mean monoploid genome size $(1 \mathrm{C} x)$ of taxonomic sections, species, and grex ranged from $0.43 \mathrm{pg}$ in $A$. carpinifolium (section Indivisa) to $1.66 \mathrm{pg}$ in A. caudatifolium (section Macrantha) (Table 3).

Cytology confirmed accessions of A. campestre (section Platanoidea) observed in this study are diploids (Fig. 1) with a mean relative $2 \mathrm{C}$ genome size of $2.01 \mathrm{pg}$ using DAPI and 1.50 pg using PI (Table 4) compared with the reported $2 \mathrm{C}$ value of 
Table 3. Average monoploid (1Cx) genome size for taxonomic sections, species, and grex of Acer using flow cytometry analysis of nuclei stained with 4',6-diamidino-2-phenylindole with Pisum sativum 'Ctirad' as the internal standard $(2 \mathrm{C}=8.76 \mathrm{pg})$.

\begin{tabular}{|c|c|c|c|}
\hline Section & $1 \mathrm{Cx}(\mathrm{pg})$ & Species/grex & $1 \mathrm{C} x[$ mean $\pm \mathrm{sE}(\mathrm{pg})]$ \\
\hline \multirow[t]{11}{*}{ Acer } & $0.93 \mathrm{efg}^{\mathrm{z}}$ & A. caesium & $1.03 \pm 0.02$ \\
\hline & & A. heldreichii & $0.88 \pm 0.01$ \\
\hline & & A. grandidentatum ${ }^{\mathrm{y}}$ & $0.84 \pm 0.00$ \\
\hline & & A. hyrcanum & $0.97 \pm 0.03$ \\
\hline & & A. monspessulanum ${ }^{\mathrm{y}}$ & $1.01 \pm 0.01$ \\
\hline & & A. opalus & $1.02 \pm 0.03$ \\
\hline & & A. pseudoplatanus & $0.86 \pm 0.03$ \\
\hline & & A. saccharum & $0.89 \pm 0.02$ \\
\hline & & A. sempervirens ${ }^{\mathrm{y}}$ & $0.95 \pm 0.02$ \\
\hline & & A. velutinum & $0.89 \pm 0.05$ \\
\hline & & A. $\times$ coriaceum $^{\mathrm{y}}$ & $0.93 \pm 0.02$ \\
\hline \multirow[t]{4}{*}{ Arguta } & $0.95 \mathrm{def}$ & A. acuminatum & $0.97 \pm 0.01$ \\
\hline & & A. argutum & $0.92 \pm 0.03$ \\
\hline & & A. barbinerve & $0.93 \pm 0.05$ \\
\hline & & A. stachyophyllum ${ }^{\mathrm{y}}$ & $0.97 \pm 0.01$ \\
\hline \multirow[t]{3}{*}{ Ginnala } & 0.80 ghi & A. tataricum $^{\mathrm{y}}$ & $0.83 \pm 0.01$ \\
\hline & & $\begin{array}{l}\text { A. tataricum ssp. } \\
\text { aidzuense }\end{array}$ & $0.82 \pm 0.01$ \\
\hline & & A. tataricum ssp. ginnala & $0.79 \pm 0.01$ \\
\hline Glabra & 0.79 ghi & A. glabrum $^{\mathrm{y}}$ & $0.79 \pm 0.03$ \\
\hline Indivisa & $0.43 \mathrm{j}$ & A. carpinifolium & $0.43 \pm 0.02$ \\
\hline \multirow[t]{3}{*}{ Lithocarpa } & $1.11 \mathrm{bc}$ & A. diabolicum & $1.19 \pm 0.00$ \\
\hline & & A. sterculiaceum ${ }^{\mathrm{y}}$ & $1.14 \pm 0.01$ \\
\hline & & A. yangbiense $e^{\mathrm{y}}$ & $0.95 \pm 0.02$ \\
\hline \multirow[t]{13}{*}{ Macrantha } & $1.32 \mathrm{a}$ & A. caudatifolium ${ }^{\mathrm{y}}$ & $1.66 \pm 0.04$ \\
\hline & & A. crataegifolium $^{\mathrm{y}}$ & $1.52 \pm 0.01$ \\
\hline & & A. davidii & $1.28 \pm 0.01$ \\
\hline & & A. forrestii ${ }^{\mathrm{y}}$ & $1.39 \pm 0.04$ \\
\hline & & A. laxiflorum ${ }^{\mathrm{y}}$ & $0.81 \pm 0.01$ \\
\hline & & A. morrisonense & $1.46 \pm 0.02$ \\
\hline & & A. pectinatum ${ }^{\mathrm{y}}$ & $1.17 \pm 0.02$ \\
\hline & & A. pensylvanicum & $1.22 \pm 0.01$ \\
\hline & & A. rubescens ${ }^{\mathrm{y}}$ & $1.46 \pm 0.05$ \\
\hline & & A. rufinerve & $1.40 \pm 0.06$ \\
\hline & & A. tegmentosum & $1.26 \pm 0.04$ \\
\hline & & A. tschonoskii ${ }^{\mathrm{y}}$ & $1.08 \pm 0.02$ \\
\hline & & A. davidii $\times$ tegmentosum & $1.38 \pm 0.03$ \\
\hline Macrophylla & $0.83 \mathrm{fgh}$ & A. macrophyllum & $0.83 \pm 0.01$ \\
\hline \multirow[t]{3}{*}{ Negundo } & $0.75 \mathrm{hi}$ & A. cissifolium $^{\mathrm{y}}$ & $0.76 \pm 0.01$ \\
\hline & & A. henryi & $0.79 \pm 0.00$ \\
\hline & & A. negundo & $0.72 \pm 0.02$ \\
\hline \multirow[t]{2}{*}{ Oblonga } & $1.16 \mathrm{~b}$ & A. albopurpurascens ${ }^{\mathrm{y}}$ & $1.15 \pm 0.00$ \\
\hline & & A. oblongum & $1.18 \pm 0.00$ \\
\hline \multirow[t]{13}{*}{ Palmata } & 0.99 cde & A. amoenum $^{\mathrm{y}}$ & $1.00 \pm 0.01$ \\
\hline & & A. campbellii ${ }^{\mathrm{y}}$ & $0.98 \pm 0.02$ \\
\hline & & A. ceriferum ${ }^{\mathrm{y}}$ & $1.01 \pm 0.01$ \\
\hline & & A. circinatum & $0.92 \pm 0.03$ \\
\hline & & A. elegantulum ${ }^{\mathrm{y}}$ & $1.00 \pm 0.03$ \\
\hline & & A. erianthum ${ }^{\mathrm{y}}$ & $1.09 \pm 0.02$ \\
\hline & & A. fabri & $1.15 \pm 0.02$ \\
\hline & & A. japonicum ${ }^{\mathrm{y}}$ & $0.94 \pm 0.00$ \\
\hline & & A. olivaceum ${ }^{\mathrm{y}}$ & $1.04 \pm 0.01$ \\
\hline & & A. oliverianum ${ }^{\mathrm{y}}$ & $1.07 \pm 0.01$ \\
\hline & & A. palmatum & $0.96 \pm 0.01$ \\
\hline & & A. pauciflorum & $0.96 \pm 0.04$ \\
\hline & & A. pseudosieboldianum & $0.95 \pm 0.01$ \\
\hline
\end{tabular}

Continued next page
$1.38 \mathrm{pg}$ for diploids (Table 1). We did not observe any tetraploid $A$. campestre or variation in holoploid genome size among accessions, which is in contrast with SiljakYakovlev et al. (2010), who identified diploid $(2 \mathrm{C}=1.38 \mathrm{pg})$ and tetraploid $(2 \mathrm{C}=2.70 \mathrm{pg})$ cytotypes.

The monoploid genome size of section Acer was calibrated using root squashes of $A$. saccharum (Fig. 1). The tetraploid $A$. pseudoplatanus was also confirmed through genome sizing. The $2 \mathrm{C}$ genome size for $A$. pseudoplatanus using PI was reported as $2.70 \mathrm{pg}$ (Siljak-Yakovlev et al., 2010), which agrees with our findings for $A$. pseudoplatanus (U.S. National Arboretum 2836) using PI $(2 \mathrm{C}=2.86 \mathrm{pg})$, but is less than our estimates using DAPI for these two accessions $(2 \mathrm{C}=3.29 \mathrm{pg}$ and 3.56 pg). Another species in section Acer reported to be tetraploid is $A$. heldreichii. Although we did not confirm this directly through cytology, the $2 \mathrm{C}$ genome size provides strong evidence $(2 \mathrm{C}=3.51 \mathrm{pg})$ that it is a tetraploid. The $2 \mathrm{C}$ value measured in the current study did not align precisely with reported values $(2 \mathrm{C}=$ $2.57 \mathrm{pg}$ ) (Siljak-Yakovlev et al., 2010). Our estimate was produced using DAPI, which regularly yields a greater genome size than PI (Table 4 ), as observed in other taxa, such as Cotoneaster (Rothleutner et al., 2016).

Cytology confirmed A. rubrum (section Rubra) OSU14-0193 is an octoploid (Fig. 1). This chromosome count provided the calibration necessary to determine the ploidy levels of other accessions of section Rubra. Genome size calibrated with cytology confirmed a natural ploidy series in $A$. rubrum, with hexaploids $(2 n=6 x=72)$ and octoploids observed in this study. There was no evidence of tetraploid $A$. rubrum among accessions analyzed. The tetraploid $A$. saccharinum was confirmed through cytological analysis (Fig. 1). Given that the monoploid genome size of species within section Rubra appears to be consistent $(1 \mathrm{C} x=0.69 \mathrm{pg})$ among many of the accessions, $A$. pycnanthum was an outlier based on our interpretation of the data $(1 \mathrm{C} x=0.99$ $\mathrm{pg})$. This is an uncommon species, endemic to the island of Honshu, 
Table 3. Continued.

\begin{tabular}{|c|c|c|c|}
\hline Section & $1 \mathrm{Cx}(\mathrm{pg})$ & Species/grex & $1 \mathrm{C} x[$ mean $\pm \mathrm{sE}(\mathrm{pg})]$ \\
\hline & & A. pubinerve & $1.05 \pm 0.02$ \\
\hline & & A. pubipalmatum & $0.99 \pm 0.03$ \\
\hline & & A. serrulatum ${ }^{\mathrm{y}}$ & $1.07 \pm 0.01$ \\
\hline & & A. shirasawanum & $1.00 \pm 0.05$ \\
\hline & & A. sieboldianum & $0.93 \pm 0.04$ \\
\hline & & A. sinense & $1.04 \pm 0.03$ \\
\hline & & A. wuyuanense & $1.01 \pm 0.00$ \\
\hline & & $\begin{array}{l}\text { A. pseudosieboldianum } \times \\
\text { A. palmatum }\end{array}$ & $1.01 \pm 0.03$ \\
\hline Parviflora & $1.03 \mathrm{bcde}$ & A. distylum & $1.03 \pm 0.01$ \\
\hline \multirow{3}{*}{ Pentaphylla } & 1.00 cde & A. buergerianum & $1.05 \pm 0.01$ \\
\hline & & A. pentaphyllum ${ }^{\mathrm{y}}$ & $0.88 \pm 0.00$ \\
\hline & & A. $y u i^{\mathrm{y}}$ & $0.78 \pm 0.01$ \\
\hline \multirow[t]{16}{*}{ Platanoidea } & $0.97 \mathrm{de}$ & A. amplum ${ }^{\mathrm{y}}$ & $1.11 \pm 0.03$ \\
\hline & & A. campestre & $1.02 \pm 0.01$ \\
\hline & & A. cappadocicum & $1.01 \pm 0.03$ \\
\hline & & A. mayrii ${ }^{\mathrm{y}}$ & $1.00 \pm 0.01$ \\
\hline & & A. miyabei & $1.00 \pm 0.04$ \\
\hline & & A. mono $^{\mathrm{y}}$ & $0.92 \pm 0.01$ \\
\hline & & A. okamotoanum & $0.93 \pm 0.04$ \\
\hline & & A. pictum & $0.96 \pm 0.02$ \\
\hline & & A. platanoides & $0.92 \pm 0.01$ \\
\hline & & A. shenkanense & $0.99 \pm 0.04$ \\
\hline & & A. truncatum & $0.95 \pm 0.03$ \\
\hline & & A. $\times$ dieckii $^{\mathrm{y}}$ & $0.99 \pm 0.00$ \\
\hline & & A. $\times$ hillieri $^{\mathrm{y}}$ & $0.95 \pm 0.02$ \\
\hline & & A. ×zoeschense & $0.94 \pm 0.00$ \\
\hline & & A. campestre $\times$ A. miyabei & $0.95 \pm 0.01$ \\
\hline & & $\begin{array}{l}\text { A. platanoides } \times A \text {. } \\
\text { truncatum }\end{array}$ & $0.91 \pm 0.01$ \\
\hline \multirow[t]{2}{*}{ Pubescentia } & 0.83 fghi & A. pentapomicum ${ }^{\mathrm{y}}$ & $0.90 \pm 0.01$ \\
\hline & & A. pilosum & $0.79 \pm 0.01$ \\
\hline \multirow[t]{4}{*}{ Rubra } & $0.69 \mathrm{i}$ & A. pycnanthum & $0.99 \pm 0.01$ \\
\hline & & A. rubrum & $0.66 \pm 0.01$ \\
\hline & & A. saccharinum & $0.66 \pm 0.03$ \\
\hline & & A. $\times$ freemanii & $0.67 \pm 0.01$ \\
\hline \multirow[t]{2}{*}{ Spicata } & 0.99 cde & A. caudatum & $0.97 \pm 0.04$ \\
\hline & & A. spicatum $^{\mathrm{y}}$ & $1.03 \pm 0.03$ \\
\hline \multirow[t]{7}{*}{ Trifoliata } & $1.02 \mathrm{bcd}$ & A. griseum $^{\mathrm{y}}$ & $0.96 \pm 0.03$ \\
\hline & & A. maximowiczianum & $1.11 \pm 0.02$ \\
\hline & & A. nikoense $\mathrm{e}^{\mathrm{y}}$ & $0.95 \pm 0.03$ \\
\hline & & A. triflorum ${ }^{\mathrm{y}}$ & $0.90 \pm 0.06$ \\
\hline & & A. griseum $\times A$. nikoense $e^{\mathrm{y}}$ & $0.98 \pm 0.01$ \\
\hline & & A. griseum $\times$ A. triflorum $^{\mathrm{y}}$ & $0.95 \pm 0.01$ \\
\hline & & $\begin{array}{l}\text { A. } \\
\text { griseum }^{\mathrm{y}}\end{array}$ & $1.07 \pm 0.01$ \\
\hline Tukey's HSD & 0.1378 & & \\
\hline
\end{tabular}

${ }^{\mathrm{Z}}$ Values within column followed by different letters are significantly different based on Tukey's honestly significant difference (HSD; $\alpha=0.05$ ).

${ }^{\mathrm{y}}$ Three samples of one accession were used to calculate the average $1 \mathrm{C} x$ value as a result of the lack of biological replicates.

Japan, that has been reported as a hexaploid $(2 n=6 x=78)$. Given the monoploid value of section Rubra is consistent, the measured genome size indicated it was an octoploid (van Gelderen et al., 1994). Cytological investigation is needed to confirm ploidy for this accession.

Acer carpinifolium (section Indivisa) was reported to be a tetraploid (Taylor, 1920) with a holoploid genome size of 0.75 pg (Olszewska and Osiecka, 1984). Our 2C estimate using PI was 1.36 pg. Based on available reports, there has not been a study that simultaneously investigated this species with flow cytometry and cytology. As a result of the prevalence of ploidy variation in the genus, it appears there are diploid and tetraploid cytotypes of $A$. carpinifolium. Olszewska and Osiecka (1984) included a diploid cytotype whereas Taylor (1920) and the current study included tetraploids. However, both the accession included in the current study and that used by Olszewska and Osiecka (1984) were received from Rogów Arboretum, Poland. Because plants of garden origin may hybridize freely, it is possible that hybrid seed was received by one or both groups. We attempted to use cytology to confirm our findings but were unable to as a result of difficulty in breaking down the cells walls sufficiently to allow for adequate spreading of metaphase cells. Although the cell walls of all other species in the cytological study were broken down effectively with enzyme digestion, A. carpinifolium proved to be recalcitrant. It may be necessary to attempt another method of cell wall digestion, such as long-term enzyme digestion on slides (Lattier et al., 2017), which yielded excellent results in identifying triploid $A$. ginnala in addition to five other diverse species.

Often, genome size data among diverse taxa of a given family are compared using the monoploid genome size because of ploidy variation. There were some significant differences among monoploid genome sizes of the 18 sections $(P<$ $0.0001)$. The greatest mean monoploid genome size was of section Macrantha (1.32 pg), which was significantly greater than all other sections. Section Indivisa had the smallest monoploid genome size based on reported ploidy and cytometric analysis $(1 \mathrm{C} x=0.43 \mathrm{pg})$. Monoploid genome size was wide ranging and somewhat regularly distributed from low to high, with a noticeable gap between sections Indivisa and Rubra (Fig. 2). Based on personal observations of successful, but accidental or "naturally" occurring intersectional hybrids that arose when nursery crops were grown in proximity to native species [e.g., A. griseum (section Trifoliata) $\times$ A. macrophyllum (section Macrophylla)], monoploid genome 
Table 4. Base pair composition of 48 Acer taxa determined by comparing holoploid (2C) genome size determined using flow cytometry analysis of nuclei stained with 4',6-diamidino-2-phenylindole (DAPI) and propidium iodide (PI) using Pisum sativum 'Ctirad' as the internal standard $(2 \mathrm{C}=8.76 \mathrm{pg})$.

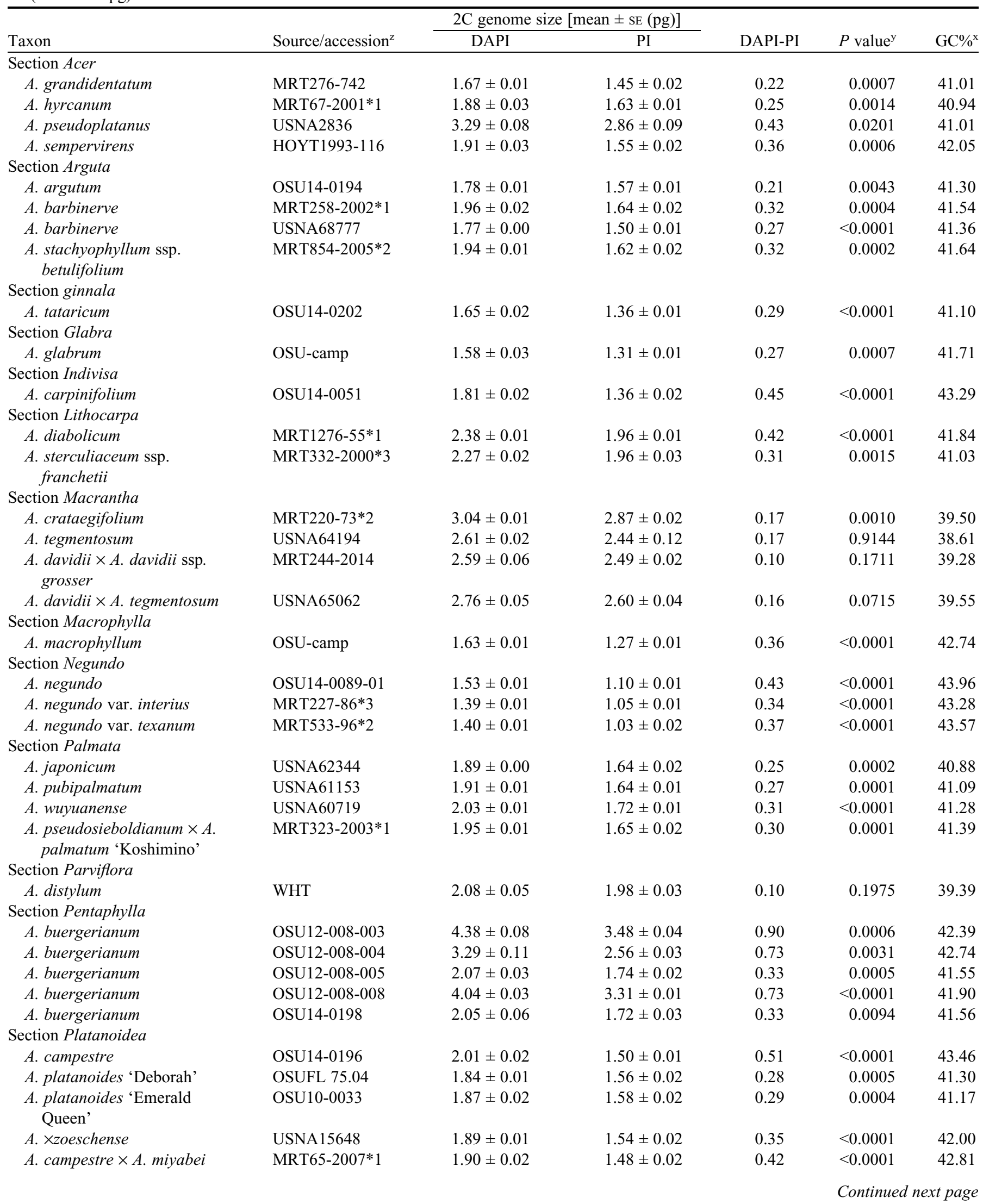


Table 4. Continued.

\begin{tabular}{|c|c|c|c|c|c|c|}
\hline \multirow[b]{2}{*}{ Taxon } & \multirow[b]{2}{*}{ Source/accession ${ }^{\mathrm{z}}$} & \multicolumn{2}{|c|}{$2 \mathrm{C}$ genome size $[$ mean $\pm \mathrm{SE}(\mathrm{pg})]$} & \multirow[b]{2}{*}{ DAPI-PI } & \multirow[b]{2}{*}{$P$ value ${ }^{\mathrm{y}}$} & \multirow[b]{2}{*}{$\mathrm{GC} \%{ }^{\mathrm{x}}$} \\
\hline & & DAPI & PI & & & \\
\hline \multicolumn{7}{|l|}{ Section Pubescentia } \\
\hline A. pentapomicum & MRT560-2001*2 & $1.80 \pm 0.01$ & $1.43 \pm 0.01$ & 0.37 & $<0.0001$ & 42.36 \\
\hline \multicolumn{7}{|l|}{ Section Rubra } \\
\hline A. rubrum & OSU14-0193 & $5.01 \pm 0.04$ & $4.37 \pm 0.03$ & 0.64 & 0.0002 & 40.90 \\
\hline A. rubrum 'Celebration' & OSU14-0183 & $3.94 \pm 0.02$ & $3.27 \pm 0.12$ & 0.67 & 0.0046 & 41.71 \\
\hline A. ×freemanii 'Autumn Blaze' & OSU14-0181 & $3.80 \pm 0.03$ & $3.30 \pm 0.06$ & 0.50 & 0.0018 & 40.92 \\
\hline A. ×freemanii 'Jenner' & MRT349-2005*1 & $3.84 \pm 0.04$ & $3.37 \pm 0.01$ & 0.47 & 0.0004 & 40.74 \\
\hline \multicolumn{7}{|l|}{ Section Spicata } \\
\hline $\begin{array}{l}\text { A. caudatum ssp. } \\
\text { ukurunduense }\end{array}$ & HOYT2014-041 & $1.88 \pm 0.03$ & $1.68 \pm 0.01$ & 0.20 & 0.0053 & 40.52 \\
\hline A. spicatum & HOYT1989-057 & $2.06 \pm 0.06$ & $1.80 \pm 0.01$ & 0.26 & 0.0122 & 40.87 \\
\hline A. griseum $\times$ A. nikoense & MRT243-94*1 & $1.96 \pm 0.02$ & $1.59 \pm 0.03$ & 0.37 & 0.0007 & 42.08 \\
\hline
\end{tabular}

${ }^{\mathrm{z}} \mathrm{ARN}=$ Arnold Arboretum, Boston, MA; COR = Cornell Plantations, Ithaca, NY; HOYT, Hoyt Arboretum, Portland, OR; JFS = J. Frank Schmidt Arboretum, Boring, OR; MRS = Morris Arboretum, Philadelphia, PA; MRT = Morton Arboretum, Lisle, IL; OSU = Oregon State University Ornamental Plant Breeding Collection, Corvallis, OR; OSU-camp = OSU campus landscape plants, Corvallis, OR; OSU-FL = field-planted material located at the Lewis-Brown Farm, Corvallis, OR; QHBG = Quarry Hill Botanical Garden, Glen Ellen, CA; USNA = U.S. National Arboretum, Washington, DC; WHT $=$ Whitman Farms, Salem, OR. Use of * within MRT accessions is a convention used within that organization's accessioning method.

${ }^{\mathrm{y}} P$ value based on paired $t$ test comparing mean holoploid genome sizes determined using DAPI with PI.

${ }^{\mathrm{x}} \mathrm{GC} \%=100-\{\mathrm{AT} \%$ for internal standard $\times[$ (mean fluorescence standard DAPI / mean fluorescence sample DAPI) $/$ (mean fluorescence standard PI / mean fluorescence sample PI) $\left.]^{(1 / \text { binding length) }}\right\}$ (Godelle et al., 1993), where AT\% of internal standard $=61.5$ and binding length of DAPI $=3.5 \mathrm{bp}$ (Meister and Barow, 2007).

size could be used as a tool for assessing hybridization that is more rapid and easier than molecular markers. Monoploid genome size within a section does not appear to be significantly different, with the exception of section Pentaphylla and potentially section Rubra if $A$. pycnanthum is proved to be a hexaploid.

Based on average monoploid genome sizes calibrated by intrasectional cytological analysis, three potential natural triploids $(2 n=3 x=39)$ have been identified: $A$. elegantulum and $A$. sinsense of section Palmata, and a hybrid accession from the Morton Arboretum identified as a cross between $A$. griseum and A. triflorum (section Trifoliata). Confirmation of triploidy through cytological assessment would be ideal. Although A. elegantulum is the accepted name of the species, another accession in this study carries the synonym $A$. olivaceum. The relative genome sizes of these two plants is significantly different: $2 \mathrm{C}=3.01 \mathrm{pg}$ and $2 \mathrm{C}=2.08 \mathrm{pg}$, respectively. If the two can be grouped together taxonomically, then this difference in genome size would further support the putative triploidy of $A$. elegantulum. If the $A$. elegantulum accession is indeed a diploid, then this genome size data would indicate further examples of multiple cytotypes within a species $(2 x$ and $3 x)$ or could support taxonomic separation of these species.

In the fluorochrome comparison, there was a significant difference in mean relative genome size measurements in 44 of the 48 accessions measured, with samples measured using DAPI being consistently larger (Table 4). It is interesting that within section Macrantha, three of the four taxa used to compare DAPI and PI were not statistically different (Table 4). The lack of difference in genome size estimation between fluorochromes in section Macrantha (39.2\% GC) is a result of its similarity in base composition to the internal standard (38.5\% GC). There was no difference in genome size estimate between fluorochromes for A. distylum (section Parviflora; $39.4 \% \mathrm{GC}$ ) and this was the only other section that had a GC\% less than $40 \%$. Other interesting points noted in section Macrantha were that it had the lowest GC\% among sections and, as discussed previously, had the largest monoploid genome size. Doležel et al. (1992) noted an overestimation of genome size using DAPI when they compared PI, DAPI, and mithramycin. Factors contributing to this overestimation include differences in base composition or sequence between the internal standard and measured sample, and differences in binding properties of the fluorochromes. Thus, there is the potential for overestimation of genome size when using basespecific fluorochromes such as DAPI; however, it is still a useful, effective, efficient, and inexpensive means to estimate a relative genome size. In addition, it can provide a tool for estimating base composition when used in conjunction with an intercalating dye such as PI.

In a recent genomic characterization study, base composition for sugar maple (A. saccharum) was determined using whole-genome sequencing. Staton et al. (2015) determined that the $\mathrm{GC} \%$ for the sugar maple sample was $38.1 \%$. Although $A$. saccharum was not evaluated using PI, four accessions of section Acer had an average GC\% of $41.2 \%$ (Table 4). Although monoploid genome size was wide 


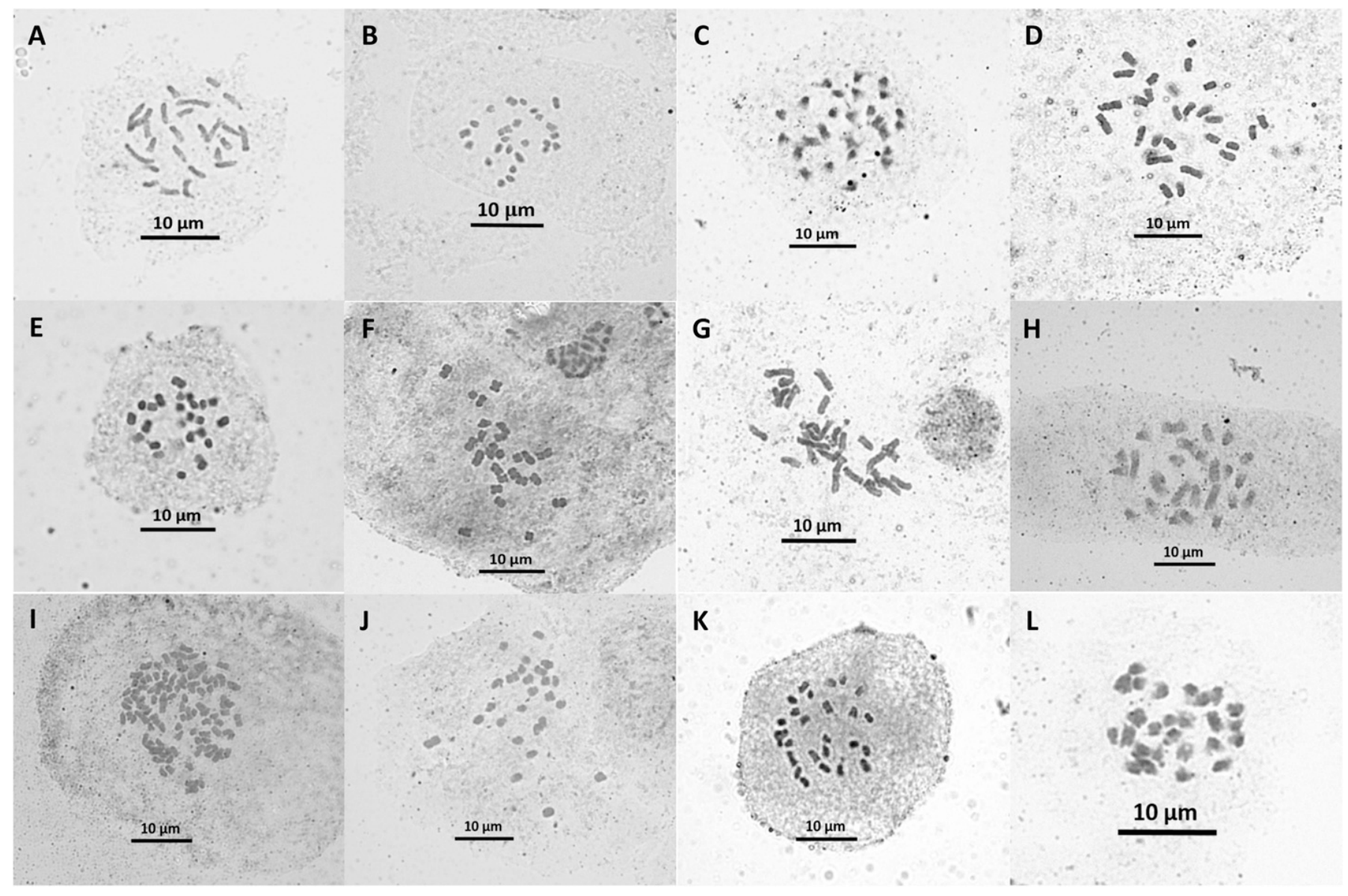

Fig. 1. Photomicrographs of root apical meristem cells from six diploid Acer species. Chromosomes stained using modified carbol-fuchsin. (A) A. albopurpurascens QHBG2003-088 $(2 n=2 x=26)$. (B) A. amplum QHBG2009-235 $(2 n=2 x=26)$. (C) A. argutum OSU14-0194 $(2 n=2 x=26)$. (D) A. buergerianum OSU14-0158 $(2 n=2 x=26)$. (E) A. campestre OSU14-0196 $(2 n=2 x=26)$. (F) A. davidii OSU14-0162 $(2 n=2 x=26)$. (G) A. macrophyllum OSU14-0059-01 $(2 n=2 x=26)$. (H) A. maximowiczianum OSU14-0150 $(2 n=2 x=26)$. (I) A. rubrum OSU14-0193 $(2 n=8 x=104)$. (J) A. saccharum OSU14-0147 $(2 n=2 x=26)$. (K) A. tataricum OSU14-0202 $(2 n=2 x=26)$. (L) A. triflorum OSU14-0143 $(2 n=2 x=26)$. Source of material used in cytological study includes Quarry Hill Botanical Garden (QHBG; Glen Ellen, CA) and Oregon State University (OSU; Corvallis, OR) accessions.

ranging, with significant differences present, there was little apparent variation in $\mathrm{GC} \%$ among the taxa evaluated in this study, ranging from just $38.61 \%$ to $43.96 \%$. It is unclear whether taxa in this study with relatively greater GC\% have any ecological advantage. However, it should be noted that norway maple (A. platanoides) is extremely ecologically adaptable- to the point of invasiveness-and has a lower GC\% (41.24\%) than bigleaf maple [A. macrophyllum $(42.74 \% \mathrm{GC})]$, which performs poorly in urban conditions and overall is less adaptable. Future studies may further investigate whether there is a correlation between $\mathrm{GC} \%$ and climate at the site of evolution of maple species.

\section{Conclusions}

This study provides valuable information for maple breeding programs, contributes to the growing database of angiosperm genome size, and provides additional data for flow cytometry methods and material. Bennett and Leitch (2005) describe "very small" genome size $(2 \mathrm{C} \leq 1.4 \mathrm{pg})$ as ancestral in angiosperms compared with "small" genome size ( $>1.4$ to $\leq 3.5 \mathrm{pg}$ ). It follows that the small genome size of Acer represents a more evolved condition. Furthermore, small genome size is often associated with developmental characters that many maples exhibit, such as rapid seedling establishment, relatively short generation time (some of our triploid A. ginnala flower in 1 year from seed), and increased reproductive rate (Bennett and Leitch, 2005). These traits contribute to evolutionary and ecological adaptability, which maples have in large order. This ecological plasticity or broad adaptability has led to many species escaping cultivation, which has prompted breeding for reduced fertility in the genus through the development of plants with odd ploidy (e.g., triploid, pentaploid). Although overall the coverage of the genus in this study is broad, there are some taxonomic sections in which there is a considerable depth of coverage, including sections Acer, Macrantha, Palmata, and Platanoi$d e a$. The current depth of coverage reflects the availability of material in arboreta, botanical gardens, and nurseries. Future work can focus on expanding our knowledge of the genus in areas with less coverage, and can aim toward continued cytological studies to provide clarification regarding ploidy and genome size. 


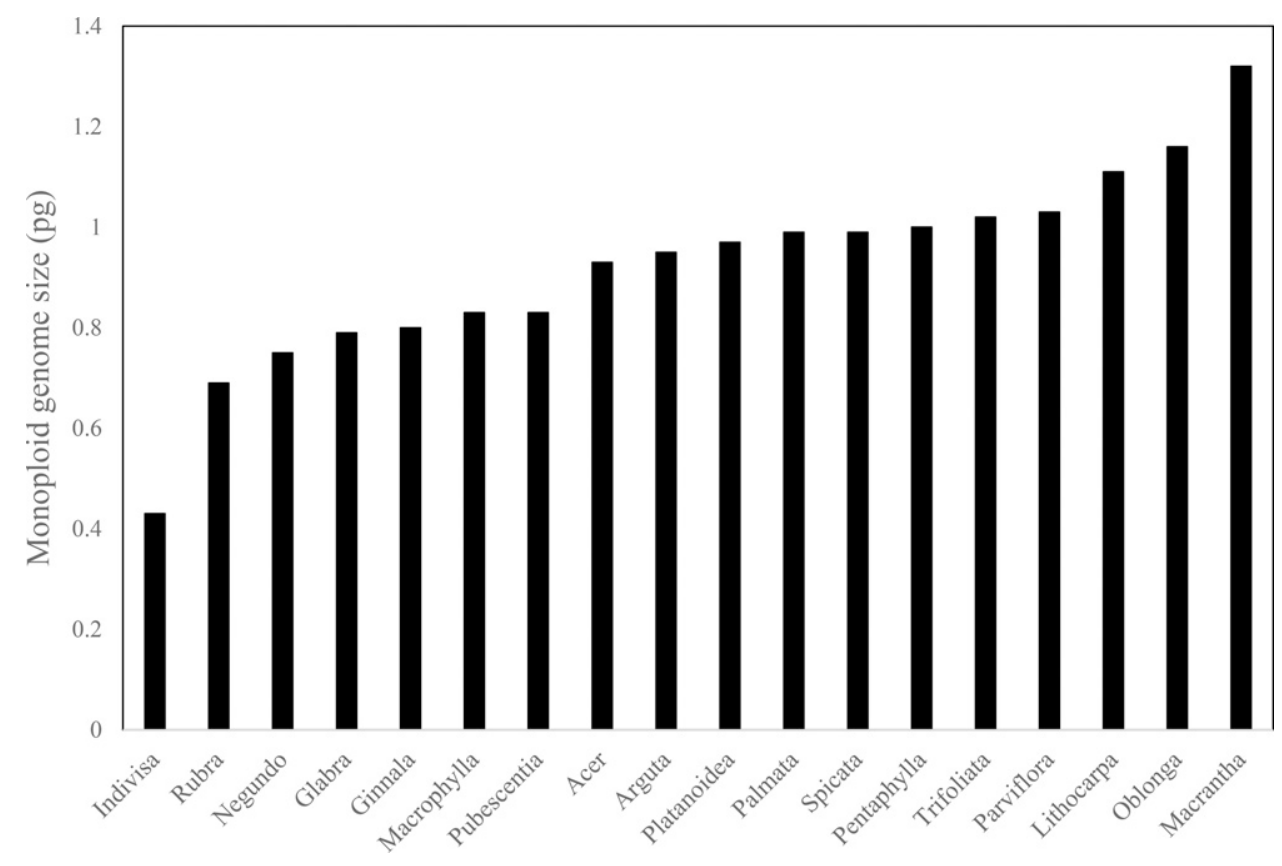

Fig. 2. Monoploid (1Cx) genome size of the 18 sections of Acer determined using flow cytometry analysis of nuclei stained with 4',6-diamidino-2-phenylindole with Pisum sativum 'Ctirad' as the internal standard $(2 \mathrm{C}=8.76 \mathrm{pg})$. and J. Suda (eds.). Flow cytometry with plant cells: Analysis of genes, chromosomes and genomes. WileyVCH, Weinheim, Germany.

Grimm, G.W., S.S. Renner, A. Stamatakis, and V. Hemleben. 2006. A nuclear ribosomal DNA phylogeny of Acer inferred with maximum likelihood, splits graphs, and motif analysis of 606 sequences. Evol. Bioinform. Online 2:7-22.

Johnston, J.S., A.E. Pepper, A.E. Hall, Z.J. Chen, G. Hodnett, J. Drabek, R. Lopez, and H.J. Price. 2005. Evolution of genome size in Brassicaceae. Ann. Bot. 95:229-235.

Jones, J.R., T.G. Ranney, and N.P. Lynch. 2007. Ploidy levels and relative genome sizes of diverse species, hybrids, and cultivars of Rhododendron. J. Amer. Rhododendr. Soc. 61:220-227.

Kao, K.N. 1975. A chromosomal staining method for cultured cells, p. 6364. In: O.L. Gambourg and L.R. Wetter (eds.). Plant tissue culture methods. National Research Council of Canada, Saskatoon, Canada.

Lattier, J.D., H. Chen, and R.N. Contreras. 2017. Improved method of enzyme di-

\section{Literature Cited}

Ackerly, D.D. and M.J. Donoghue. 1998. Leaf size, sapling allometry, and Corner's rules: Phylogeny and correlated evolution in maples (Acer). Amer. Nat. 152:767-791.

Aiello, A.S. and M.S. Dosmann. 2010. By the numbers: Twenty years of NACPEC collections. Arnoldia 68:20-35.

Bai, C., W.S. Alverson, A. Follansbee, and D.M. Waller. 2012. New reports of nuclear DNA content for 407 vascular plant taxa from the United States. Ann. Bot. (Lond.) 110:1623-1629.

Bennett, M.D. and I.J. Leitch. 2005. Genome size evolution in plants, p. 89-162. In: T.R. Gregory (ed.). The evolution of the genome. Elsevier, San Diego, CA.

Bennett, M.D. and I.J. Leitch. 2012. Plant DNA C-values database (release 6.0, Dec. 2012). 16 July 2016. <http://www.kew.org/ cvalues/>.

Contreras, R.N. and J.M. Ruter. 2011. Genome size estimates and chromosome numbers of Callicarpa L. (Lamiaceae). HortScience 46:567-570.

Darlington, C.D. and A.P. Wylie. 1956. Chromosome atlas of flowering plants. MacMillan, New York, NY.

Doležel, J., S. Sgorbati, and S. Lucretti. 1992. Comparison of three DNA fluorochromes for flow cytometric estimation of nuclear DNA content in plants. Physiol. Plant. 85:625-631.

Duffield, J.W. 1943. Polyploidy in Acer rubrum L. Chron. Bot. 8:390391.

eFlora. 2016. Flora of China. 15 July 2016. <http://www.efloras.org/ florataxon.aspx?flora_id=2\&taxon_id=100167>.

Foster, R.C. 1933. Chromosome number of Acer and Staphylea. J. Arnold Arbor. 14:386-392.

Galbraith, D.W., J.L. Bennetzen, E.A. Kellogg, J.C. Pires, and P.S. Soltis. 2011. The genomes of all angiosperms: A call for a coordinated global census. J. Bot. 11:646198, doi: 10.1155/2011/646198.

Godelle, B., D. Cartier, D. Marie, S.C. Brown, and S. Siljak-Yakovlev. 1993. Heterochromatin study demonstrating the non-linearity of fluorometry useful for calculating genomic base composition. Cytometry 14:618-626.

Greilhuber, J., E.M. Temsch, and J.C.M. Loureiro. 2007. Nuclear DNA content measurement, p. 67-101. In: J. Doležel, J. Greilhuber, gestion for root tip cytology. HortScience 52:1029-1032.

Lattier, J.D., T.G. Ranney, P.R. Fantz, and T. Avent. 2014. Identification, nomenclature, genome sizes, and ploidy levels of Liriope and Ophiopogon taxa. HortScience 49:145-151.

Li, J. 2011. Phylogenetic evaluation of series delimitations in section Palmata (Acer, Aceroideae, Sapindaceae) based on sequences of nuclear and chloroplast genes. Aliso 29:43-49.

Li, J. 2016. Maple phylogeny. 15 July 2016. <http://www2.huh. harvard.edu/research/jli/maples.html>.

Li, J., J. Yue, and S. Shoup. 2006. Phylogenetics of Acer (Aceroideae, Sapindaceae) based on nucleotide sequences of two chloroplast noncoding regions. Harv. Pap. Bot. 11:101-115.

Li, X.-Q. and D. Du. 2014. Variation, evolution, and correlation analysis of $\mathrm{C}+\mathrm{G}$ content and genome or chromosome size in different kingdoms and phyla. PLoS One 9:e88339, doi: 10.1371/journal. pone.0088339.

Loureiro, J., E. Rodriguez, J. Doležel, and C. Santos. 2007. Two new nuclear isolation buffers for plant DNA flow cytometry: A test with 37 species. Ann. Bot. 100:875-888.

Meister, A. and M. Barow. 2007. DNA base composition of plant genomes, p. 177-213. In: J. Doležel, J. Greilhuber, and J. Suda (eds.). Flow cytometry with plant cells: Analysis of genes, chromosomes and genomes. Wiley-VCH, Weinheim, Germany.

Olsen, R.T., T.G. Ranney, and D.J. Werner. 2006. Fertility and inheritance of variegated and purple foliage across a polyploid series in Hypericum androsaemum L. J. Amer. Soc. Hort. Sci. 131:725-730.

Olszewska, M.J. and R. Osiecka. 1984. The relationship between 2C DNA content, systematic position, and the level of nuclear DNA endoreduplication during differentiation of root parenchyma in some dicotyledonous shrubs and trees: Comparison with herbaceous species. Biochem. Physiol. Pflanz. 179:641-657.

Parris, J.K., T.G. Ranney, H.T. Knap, and W.V. Baird. 2010. Ploidy levels, relative genome sizes, and base pair composition in Magnolia. J. Amer. Soc. Hort. Sci. 135:533-547.

Pfosser, M.F., J. Guzy-Wrobelska, B.Y. Sun, T.F. Stuessy, T. Sugawara, and N. Fujii. 2002. The origin of species of Acer (Sapindaceae) endemic to Ullung Island, Korea. Syst. Bot. 27:351-367.

Renner, S.S., G.W. Grimm, G.M. Schneeweiss, and T.F. Stuessy. 2008. Rooting and dating maples (Acer) with an uncorrelated rates 
molecular clock: Implications for North American/Asian disjunctions. Syst. Biol. 57:795-808.

Rothleutner, J.J., M.W. Friddle, and R.N. Contreras. 2016. Ploidy levels, relative genome sizes, and base pair composition in $\mathrm{Co}$ toneaster. J. Amer. Soc. Hort. Sci. 141:457-466.

Rounsaville, T.J. and T.G. Ranney. 2010. Ploidy levels and genome sizes of Berberis L. and Mahonia Nutt. species, hybrids, and cultivars. HortScience 45:1029-1033.

Sanford, J.C. 1983. Ploidy manipulations, p. 100-123. In: J.N. Moore and J. Janick (eds.). Methods in fruit breeding. Purdue University Press, West Lafayette, IN.

Santamour, Jr., F.S. 1965. Cytological studies in red and silver maples and their hybrids. Bull. Torrey Bot. Club 92:127-134.

Santamour, Jr., F.S. 1971. IOPB chromosome number reports: XXXII. Taxon 20:355.

Santamour, Jr., F.S. 1988. New chromosome counts in Acer (maple) species, sections, Acer and Goniocarpa. Rhodora 90:127-131.

Shearer, K. and T.G. Ranney. 2013. Ploidy levels and relative genome sizes of species, hybrids, and cultivars of dogwood (Cornus spp.). HortScience 48:825-830.

Siljak-Yakovlev, S., F. Pustahija, E.M. Solic, F. Bogunic, E. Muratovic, N. Basic, O. Catrice, and S.C. Brown. 2010. Towards a genome size and chromosome number database of Balkan flora: C-values in 343 taxa with novel values for 242. Adv. Sci. Lett. 3:190-213.

Šmarda, P., P. Bureš, L. Horová, I.J. Leitch, L. Mucina, E. Pacini, L. Tichý, V. Grulich, and O. Rotreklová. 2014. Ecological and evolutionary significance of genomic GC content diversity in monocots. Proc. Natl. Acad. Sci. USA 111:E4096-E4102.

Soltis, D.E., P.S. Soltis, M.D. Bennett, and I.J. Leitch. 2003. Evolution of genome size in the angiosperms. Amer. J. Bot. 90:1596-1603.

Staton, M., T. Best, S. Khodwekar, S. Osusu, T. Xu, Y. Xu, T. Jennings, R. Cronn, A.K. Arumuganathan, M. Coggeshall, O. Gailing, H. Liang, J. Romero-Severson, S. Schlarbaum, and J.E. Carlson. 2015. Preliminary genomic characterization of ten hardwood species from multiplexed low coverage whole genome sequencing. PLoS One 10:e145031, doi: 10.1371/journal. pone.0145031.

Suh, Y., K. Heo, and C.-W. Park. 2000. Phylogenetic relationships of maples (Acer L.; Aceraceae) implied by nuclear ribosomal ITS sequences. J. Plant Res. 113:193-202.

Takizawa, S. 1952. Chromosome studies in the genus Acer L. I. The chromosome constitution of the genus Acer. J. Faculty Sci., Hokkaido Univ. Ser. 5 Bot. 6:249-272.

Taylor, W.R. 1920. A morphological and cytological study of reproduction in the genus Acer. Contrib. Bot. Lab. Univ. Pennsylvania 5:111-138.

The Arnold Arboretum of Harvard University. 2016. Expeditions unveiled. 16 July 2016. <http://www.arboretum.harvard.edu/plants/ plant-exploration/expeditions-unveiled/>.

Tian, X., Z.H. Guo, and D.Z. Li. 2002. Phylogeny of Aceraceae based on ITS and trnL-F data sets. Acta Bot. Sin. 44:714-724.

Trueblood, C.E., T.G. Ranney, N.P. Lynch, J.C. Neal, and R.T. Olsen. 2010. Evaluating fertility of triploid clones of Hypericum androsaemum L. for use as non-invasive landscape plants. HortScience 45:1026-1028.

U.S. Department of Agriculture. 2016. Census of horticultural specialties for 2014. 15 July 2016. <https://www.agcensus.usda. gov/Publications/2012/Online_Resources/Census_of_Horticulture_ Specialties/>.

van Gelderen, D.M., P.C. de Jong, and H.J. Oterdoom. 1994. Maples of the world. Timber Press, Portland, OR.

Yotoko, K.S.C., M.C. Dornelas, P.D. Togni, T.C. Fonseca, F.M. Salzano, S.L. Bonatoo, and L.B. Freitas. 2011. Does variation in genome sizes reflect adaptive or neutral processes? New clues from Passiflora. PLoS One 6:e18212, doi: 10.1371/journal.pone.0018212.

Zhang, Z., C. Li, and J. Li. 2010. Conflicting phylogenies of section Macrantha (Acer, Aceroideae, Sapindaceae) based on chloroplast and nuclear DNA. Syst. Bot. 35:801-810. 